\title{
Тувинский язык в правовом и функциональном измерении"
}

\author{
Тамара Г. Боргоякова \\ Хакасский государственный университет им. Н. Ф. Катанова, Российская Федерация,
} Айса Н. Биткеева

Институт языкознания РАН; Институт мировой литературы им. А. М. Горького РАН, Российская Федерация

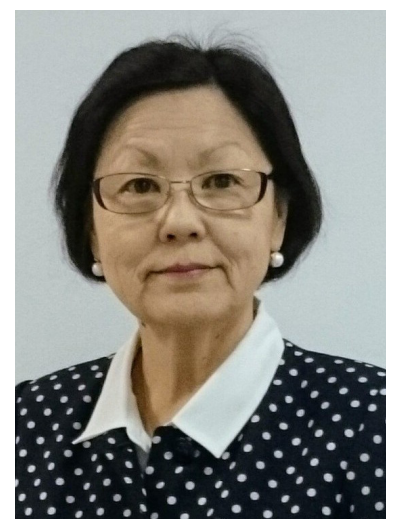

В статье анализируются позитивные и проблемные аспекты языковой политики в Республике Тыва. Несмотря на высокую демографическую мощность тувинского языка и его статус государственного языка республики, продолжаются негативные процессы языкового сдвига умолодого поколения тувинцев. Отмечается ослабление функциональной мощности тувинского языка не только как государственного, но и как родного языка титульного этноса республики.

Сегодня чуть более 50\% тувинских респондентов 18-30 лет свободно владеет родным языком и около 70\% из них разговаривает на нем с детьми. В столище республики лишь 62\% тувинских школьников изучают родной язык. В результате активными тувинско-русскими билингвами является лишь часть детей при увеличении категории русскоязычных монолингвов. В то же время есть группа сельских детей со слабым или почти нулевым владением русским языком. Выявленная противоречивость между позитивным отношением к родному языку и выбором русского для обучения в школе и даже для семейного общения связана с недоступностью или недостаточностью научной и образовательной информации о преимуществах билингвизма, об особой важности родного языка для интеллектуального и эмоционального развития детей, их психологической устойчивости.

Важной позитивной особенностью языковой политики республики является наметившийся конструктивный диалог ее основных субъектов - власти и активных защитников родного языка. Соответствующее финансирование в рамках Государственной программы развития тувинского языка 2017-2020 г2., открытое обсуждение хода ее реализации позволяет прогнозировать возможность поворота языкового сдвига и постепенное развитие сбалансированного активного тувинско-русского и русскотувинского билингвизма при сохранении межэтнического согласия в Республике Тыва.

Ключевые слова: языковая политика; тувинский язык; Тува; родной язык; активный билингвизм; языковая лояльность; языковой сдвиг; общественное обсуждение

"Исследование выполнено при финансовой поддержке РФФИ в рамках научного проекта № 20-012 -00426.

\section{Для цитирования:}

Боргоякова Т. Г., Биткеева А. Н. Тувинский язык в правовом и функциональном измерении [Электронный ресурс] // Новые исследования Тувы. 2020, № 1. URL: https://nit.tuva.asia/nit/article/view/914 (дата обращения: дд.мм. гг.). DOI: 10.25178/nit.2020.1.4

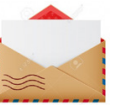

Боргоякова Тамара Герасимовна - доктор филологических наук, профессор, директор Института гуманитарных исследований и саяно-алтайской тюркологии, профессор кафедры зарубежной лингвистики и теории языка Хакасского государственного университета им. Н. Ф. Катанова. Адрес: 655017, Россия, г. Абакан, пр-т Ленина, д. 92. Тел.: +7 (390) 222-34-94. Эл. адрес: tamarabee@mail.ru ORCID ID: 0000-0001-9958-9086

Биткеева Айса Николаевна - доктор филологических наук, ведущий научный сотрудник Научно-исследовательского центра по национально-языковым отношениям Института языкознания РАН; ведущий научный сотрудник сектора фольклора Института мировой литературы им. А. М. Горького РАН. Адрес: 125009, Россия, г. Москва, Б. Кисловский пер., д. 1/1; 121069, Россия, г. Москва, ул. Поварская, д. 25а. Эл. адрес: aisa_bitkeeva@yahoo.comＯRCID ID: 0000-0003-3765-2144

Borgoiakova Tamara Gerasimovna, Doctor of Philology, Director, Research Institute of Humanities and Sayano-Altai Turkology; Professor, Department of Foreign Linguistics and Language Theory, N.F. Katanov Khakass State University. Postal address: 92 Lenin St., 655017 Abakan, Russian Federation.E-mail: tamarabee@mail.ru

Bitkeeva Aysa Nikolaevna, Doctor of Philology, Leading Research Fellow, Research Center on Ethnic and Language Relations, Institute of Linguistics, Russian Academy of Sciences; Leading Research Fellow, A. M. Gorky Institute of World Literature, Russian Academy of Sciences. Postal address: 1/1 Bolshoy Kislovsky per., 125009 Moscow, Russian Federation. E-mail: aisa_bitkeeva@yahoo.com 


\title{
Tuvan language in legal and functional aspect ${ }^{*}$
}

\author{
Tamara G. Borgoiakova \\ N.F. Katanov Khakass State University, Russian Federation, \\ Aysa N. Bitkeeva \\ Institute of Linguistics, Russian Academy of Sciences; A.M. Gorky Institute of World Literature, \\ Russian Academy of Sciences, Russian Federation
}

\begin{abstract}
The article examines both positive and negative aspects of the language policy in the Republic of Tuva. Although Tuvan language still preserves its high demographic power and the status of a state language of one of the Russia's constituent republics, the younger generation of Tuvans keeps suffering from a linguistic shift. The language is functionally weakening its position both as the state language of a region and as the first language of its titular ethnicity.

At present, slightly over 50\% respondents from among Tuvans aged 18-30 are fluent in their native tongue, and over 70\% of these speak Tuvan with their children. In the capital of the republic, only $62 \%$ of Tuvan schoolchildren study their native language. As a result, active Russian-Tuvan bilingualism is not universal among Tuvan children, while the number of those speaking only Russian keeps increasing. At the same time, in the countryside there are children who know little or almost no Russian. What is perceived as a contradiction between the positive attitude to the native language among Tuvans and the choice of Russian as the language of school education and even of family communication. This is due to the insufficiency or inaccessibility of information on the benefits of bilingualism and on the importance of one's native language for children's intellectual and emotional development, as well as their psychological stability.

An important positive factor of Tuva's language policy is the start of a dialogue between its two major actors - the authorities and language activists. Under the State Development program of supporting Tuvan language, 2017-2020, language protection will receive financial aid, and the implementation of the program will be publicly discussed. This implies an opportunity to reverse the language shift and build up a balanced Tuvan-Russian and Russian-Tuvan bilingualism while preserving the existing interethnic consensus in the Republic of Tuva.
\end{abstract}

Keywords: language policy; Tuvan language; Tuva; mother tongue; active bilingualism; language loyalty; language shift; public debate

" The research was conducted with financial support from RFBR, project № 20-012-00426.

For citation:

Borgoiakova T. G. and Bitkeeva A. N. Tuvan language in legal and functional aspect. The New Research of Tuva, 2020, no. 1 [online] Available at: https://nit.tuva.asia/nit/article/view/914 (access date ... ). DOI: 10.25178/nit.2020.1.4

\section{Введение}

2019 год был провозглашен Генеральной Ассамблей ООН годом языков коренных народов для привлечения общественного внимания к критическим рискам их витальности и повышению значимости в интересах устойчивого развития мирового сообщества. Для многоязычной России это событие стало еще одним поводом для актуализации внимания к приоритетам и динамике языковой жизни страны в контексте проводимой языковой политики с учетом международного опыта ревитализации языков коренных народов (Боргоякова, 2018). Дискуссии о необходимости гармонизации двух противоположных потребностей - языкового единства страны и стремления разных народов сохранять и развивать свои национальные языки и культуры с акцентом на региональной языковой проблематике прошли в 2019 г. в рамках ряда научных мероприятий в Сибири, включая Всероссийские конференции в Республиках Тыва и Хакасия: «Родные языки тюркских народов Сибири в современном изменяющемся мире: перспективы научных исследований, документирование, преподавание» и «Сохранение и развитие языков и культур коренных народов Сибири»ํ.

Авторы современных российских социолингвистических исследований отмечают кардинальную противоположность оценок языковой политики в последние десятилетия. Так, если в СССР требовалось писать о «благоприятных» условиях для развития всех языков, то в годы перестройки политика

\footnotetext{
${ }^{1}$ В Хакасии учёные обсуждают вопросы сохранения и развития языков и культур коренных народов Сибири (2019) [Электронный ресурс] // Федеральное агентство по делам национальностей. 17 мая. URL: http://fadn. gov.ru/news/2019/05/17/3775-v-hakasii-uchyonye-obsuzhdayut-voprosy-sohraneniya-i-razvitiya-yazykov-ikultur-korennyh-narodov-sibiri; Родные языки тюркских народов Сибири в центре научного внимания (2019) [Электронный ресурс] // Тувинский государственный университет. 19 сентября. URL: http://tuvsu.ru/news/2565/
} 
советского периода уже оценивалась как «духовно-культурно-языковой геноцид». До середины 1990-х годов отечественная социолингвистика переживала период «определенной растерянности» (Алпатов, 2018), но сегодня, на наш взгляд, она существенно продвинулась вперед в аналитической работе по оценке языковой политики России и прогнозированию развития языковой ситуации. Отмечая декларативный характер многих положений федерального языкового законодательства и сокращение языкового разнообразия, ученые обращают внимание на отсутствие четкой и продуманной языковой политики в РФ (Алпатов, 2015, 2018; Головко, 2016). И если первое было преодолено в отношении русского языка после принятия адекватного новому времени Федерального закона о государственном языке РФ, то в законодательстве республиканского уровня подобных законов или поправок, «четко устанавливающих сферы обязательного использования государственных языков республик принято не было» (Замятин, 2012: 121). Большинство положений в законах о языках народов Южной Сибири, например, ограничены разрешением использовать титульные языки в ограниченном количестве социальных сфер, во многом повторяя положения федерального языкового законодательства (Боргоякова, 2013).

Критический уровень социальной напряженности и протестной деятельности в 2018 г. был связан с введением добровольного изучения титульных языков республик РФ с переходом к более нейтральной оценке ситуации при активности устных и письменных обращений в местные органы управления с пожеланиями и требованиями уладить ситуацию (Биткеева и др., 2019). Формы их изучения в РФ были разными в зависимости от языкового законодательства республик: от обязательности изучения для всех с различиями в объеме отводимых часов (Татарстан, Башкортостан, Коми, Чувашия, Ингушетия и др.) до факультативности (Алтай, Крым, Мордовия, Удмуртия и др.) или императивности только для детей титульного этноса (Кабардино-Балкария, Чечня, Карачаево-Черкессия) (Арутюнова, 2018). Возможно, именно отсутствие единой и продуманной политики в этом вопросе приводило к недовольству и протестам русскоязычных родителей из первой группы республик.

В свою очередь внесение в Госдуму РФ законопроекта о добровольном изучении национальных языков в школах вызвало острую реакцию в национальных республиках, была создана группа «За сохранение родных языков в обязательной части учебных планов общего образования» из представителей разных народов и республик РФ (см.: Биткеева, 2018: 33).

Особенности развития тувинского языка, тувинско-русского билингвизма в постсоветский период неоднократно привлекали внимание исследователей (Мартан-оол, 2000; Боргоякова, 2002; Бавуу-Сюрюн, 2010; Ламажаa, 2014; Боргоякова, Гусейнова 2017; Цыбенова, 2017; Сэрээдар, 2018 и др.). В указанных работах отмечается более высокий уровень демографической и коммуникативной мощности тувинского языка по сравнению со многими другими языками РФ, также имеющими статус государственных на территории своих республик. Это связывается со значительно более поздним вхождением Тувинской народной Республики в состав СССР (1944г.), высокой долей коренного этноса в структуре населения республики (82\%) и сохранением его компактного проживания в сельской местности. Следующий индикатор вектора развития языковой ситуации - языковая лояльность или степень приверженности к родному языку, проявляющаяся в признании его родным, в выборе его в качестве языка обучения, языка общения (Словарь ... , 2006) - также выглядит благополучным, составляя по данным Всероссийской переписи населения 2010 г. - 96,1\%.

Но, как известно, функциональное ограничение языкового пространства в официальном дискурсе приводит к снижению социального статуса языка, сокращению или остановке естественной передачи языка детям в семье или ограничению его функционирования только семейными рамками. Именно по этой причине многие языки народов РФ, включая тувинский язык, были внесены в Атлас языков мира под угрозой исчезновения ЮНЕСКО. Тувинский язык отнесен к группе уязвимых (vulnerable) языков. В данной группе большинство детей говорят на языке, но это может быть ограничено определенными доменами (например, семьей) (most children speak the language, but it may be restricted to certain domains (e. g., home) $)^{1}$.

Наметившиеся процессы языкового сдвига, обусловленные ограниченностью сфер функционирования, становились очевидными и для рядовых носителей языка. Так, по итогам социолингвистических опросов 2013 г. 62\% тувинских респондентов считали, что будущее тувинского языка находится под угрозой (Боргоякова, Гусейнова 2017: 69-70).

${ }^{1}$ UNESCO Interactive Atlas of the World's Languages in Danger [Электронный ресурc] // UNESCO. URL: http://www. unesco.org/culture/languages-atlas/en/atlasmap.html (дата обращения: 12.04.2019). 
Цель данной статьи заключается в выявлении позитивных и проблемных аспектов языковой политики в части современного функционирования тувинского языка в Республике Тыва в контексте развития его нормативно правового статуса и содержания соответствующего научного, официального и публицистического дискурсов. Применение дискурс-анализа на материале большого спектра тувинских акторов, участвующих в дебатах о языке, предпринимается впервые и позволяет выявить и раскрыть их «аргументативные паттерны», отразить динамику языковых процессов и обнаружить области этноязыковой напряженности (см. об этом: Биткеева, Вингендер, Михальченко, 2019). К основным задачам работы относится:

- определение тенденций и изменений в правовом обеспечении функционирования тувинского языка в Туве за последние годы в контексте языковой политики РФ;

- анализ репрезентации динамики и перспектив функционирования тувинского языка в современном научном, официальном и публицистическом дискурсах;

- выявление роли основных субъектов языковой политики в Республике Тыва.

\section{Динамика развития языкового законодательства в Республике Тыва}

В Российской империи не было специального языкового законодательства и правовое урегулирование языкового разнообразия впервые было введено Законом РСФСР от 25 октября 1991 г. «О языках народов РСФСР». Конституция РФ 1993 г. создала юридические основы языковой иерархии и, руководствуясь принципами равноправия и самоопределения народов, закрепила за республиками право устанавливать свои государственные языки. Республиканские законы о языках сохранили в общих чертах структурную и содержательную часть статей Закона о языках РФ и создали базу для «государственного двуязычия» или даже «государственного многоязычия» в республиках.

В 1998 г. был принят федеральный закон «О внесении изменений и дополнений в Закон РСФСР “О языках народов РСФСР”», в соответствии с которым существенная часть полномочий в области языковой политики была передана на региональный уровень. Изменения носили столь кардинальный характер, что закон стал в сущности «его новым вариантом» (Нерознак 2002: 9). Передача большинства полномочий на уровень республик РФ произошла с помощью замены положений, предписывавших сферы и обязательность использования в них государственных языков республик, на формулировки разрешительного характера (см., напр., статьи 12, 13, 16, 23ํㅜ). Так, например, статья 7 п. 1 в редакции 1991 г. устанавливала, что государственные программы РСФСР и республик в составе РСФСР по сохранению и развитию языков народов РСФСР разрабатываются и реализуются соответствующими органами власти. В измененной редакции «органы государственной власти субъектов РФ могут разрабатывать соответствующие региональные целевые программы» ${ }^{2}$. В результате в ряде республик, в частности в Республике Хакасия, отказались от разработки и принятия долгосрочных программ по сохранению и развитию языков народов республики.

Тува была одной из первых республик, принявших закон о языках (в 1990 г.) и тувинский язык провозглашался единственным государственным языком на ее территории. За русским языком был закреплен статус языка межнационального общения. Новый закон «О языках в Республике Тыва» был принят в 2003 г. Он отменил принятый ранее республиканский закон 1990 г. и закон об изменениях к нему от 1994 г.

Новый закон устанавливает статус государственных языков республики для двух языков тувинского и русского. За русским языком также сохраняется роль «языка межнационального общения» $(\text { ст. } 2)^{3}$. К ведению органов государственной власти РТ относится «обеспечение равноправного функционирования тувинского и русского языков как государственных», а также «создание условий для функционирования языков других народов, представители которых компактно проживают на территории РТ» (ст. 5).

Анализ положений данного закона выявляет закрепление возможности использовать оба государственных языка в 12 случаях, что превышает показатели аналогичных законов в соседних рес-

\footnotetext{
${ }^{1}$ Закон Российской Федерации «О языках народов Российской Федерации» [Электронный pecypc] // Pravo.gov. ru. URL: http://pravo.gov.ru/proxy/ips/?docbody=\&nd=102012883_(дата обращения: 12.04.2019).

2 Там же.

${ }^{3}$ Закон Республики Тыва от 31 декабря 2003 года № 462 BX-I «О языках в Республике Тыва» [Электронный ресурс] // Электронный Фонд правовой и нормативно-технической документации. URL: http://docs.cntd.ru/ document/802019672 (дата обращения: 12.04.2019).
} 
публиках Алтай и Хакасия. Прежде всего, речь идет о функционировании двух государственных языков республики в органах государственной власти и местного самоуправления, при официальном опубликовании республиканских законов и других правовых актов, при проведении референдумов и выборов в представительные и исполнительные органы Республики Тыва, в работе государственных органов, организаций, предприятий и учреждений и в официальном делопроизводстве. Двуязычие распространяется также на работу СМИ и на ограниченные сферы обслуживания и коммерческой деятельности. Использование языков в сфере образования включает право на получение основного общего образования на родном языке, которое обеспечивается «созданием необходимого числа соответствующих образовательных учреждений, классов, групп, а также условий для их функционирования. При выборе языка обучения и воспитания в образовательных учреждениях создаются равные условия для изучения государственных языков РТ в соответствии с федеральными и республиканскими государственными образовательными стандартами (ст. 7, 9-13, 17, 18)1.

Впоследствии в данный закон также вносились корректировки и изменения. В частности, изменения коснулись статьи 6, в которой закрепляется формулировка «Государственные программы Республики Тыва» вместо «Республиканские целевые программы». Статус госпрограмм переводит их в инструменты стратегического планирования государственной языковой политики республики. Новый вектор развития языковой политики получил отражение в разработке и принятии государственных программ, посвященных языкам республики. Первой в республике в 2013 г. была утверждена государственная программа по развитию русского языка на период с 2014 по 2018 гг. ${ }^{2}$ Государственная программа развития тувинского языка появилась позднее, охватывая период с 2017 по 2020 гг. ${ }^{3}$ Появлению данной программы предшествовали как исследования и рекомендации ученых в области социолингвистики, так и активные и порой эмоциональные дискуссии об особенностях функционального взаимодействия государственных языков РТ с участием основных субъектов языковой политики.

Анализ положений второй государственной программы показывает, что в ее концептуальной и аналитической части учтены основные научные знания об особенностях и противоречиях официальной и неофициальной языковой политики с начала 2000-х годов, а также предложения представителей гражданского общества.

Мы вернемся к анализу данного документа ниже.

\section{Проблемы функционирования тувинского языка в социолингвистическом дискурсе}

Анализ реального софункционирования государственных языков республики - тувинского и русского - получил отражение в ряде научных публикаций, изданных после вступления в силу нового закона о языках в РТ (Бавуу-Сюрюн, 2010; Боргоякова, 2013; Цыбенова, 2017 и др.). В них содержатся выводы о слабой эффективности языковой политики в части несбалансированности функционирования государственных языков и финансирования мероприятий по их поддержке, а также о продолжающихся процессах языковой ассимиляции. Так, по мнению М. В. Бавуу-Сюрюн, «простое декларирование равноправного применения языков в различных сферах жизни общества без программного, соответствующего научного, кадрового обеспечения, финансирования из бюджетов разных уровней не дали ожидаемых положительных результатов» и в республике происходят процессы «реальной ассимиляции» (Бавуу-Сюрюн, 2010: 62). Поиск причин закрепления за тувинским языком преимущественно неофициальных сфер коммуникации приводит к выводу, что подобная функциональная дистрибуция носит не только субъективный характер, но и объясняется отсутствием «конкретных мер по расширению функций тувинского языка как государственного» (Цыбенова, 2017: 27).

\footnotetext{
${ }^{1}$ Там же.

${ }^{2}$ Государственная программа Республики Тыва «Развитие русского языка на 2014-2018 годы» [Электронный ресурс] // Министерство образования и науки Республики Тыва. URL: http://monrt.ru/images/deyatelnost/ gosrrogrammy/RazvitieRusskogoYazykaNa2014-2018.pdf (дата обращения: 12.04.2019).

${ }^{3}$ Государственная программа Республики Тыва «Развитие тувинского языка на 2017-2020 годы» [Электронный ресурс] // Электронный Фонд правовой и нормативно-технической документации. URL: http://mert.tuva.ru/directions/fcp/gp/31.html (дата обращения: 12.04.2019).
} 
В то же время происходит заметное снижение уровня владения русским языком, прежде всего, среди тувинских жителей села, что также диктует необходимость мер государственной поддержки для его более качественного преподавания в национальной школе, в которой формирование коммуникативных навыков сведено к пассивной способности только восприятия и понимания, но не порождения речи на русском языке (Сегленмей, 2007; Цыбенова, 2017: 27).

Объяснение сложившейся языковой ситуации в контексте реформ национального образования на федеральном уровне содержится в статье Г. М. Селиверстовой${ }^{1}$. Автор обращает внимание на серьезные пробелы в обучении русскому языку школьников, получающих дошкольную первичную социализацию на родном (нерусском) языке, включая, в том числе: а) низкое качество учебнометодического обеспечения, спускаемого из Федерального института развития образования; б) очередное сокращение часов на изучение русского языка на начальном этапе обучения в национальной школе. Последнее имело негативный эффект в Туве с наличием острой проблемы развития тувинскорусского двуязычия. При этом более 50\% респондентов из числа учителей начальных классов Тувы в 1993 г. поддержали готовящееся сокращение. Они все считали, что «языком обучения в тувинской школе должен быть родной язык с 1 по 10-й класс»². Кардинальные изменения в языковых установках и ориентациях были выявлены через 5 лет, когда, по итогам опроса, более 36\% опрошенных считали, что языком обучения в тувинской школе должен быть русский язык (с первого класса, оставив родной как предмет), 47,5\% - тувинский и русский языки и 15,3\% - тувинский язык 3 .

По мнению С. Ф. Сегленмей, в республике сложилась трехмерная дифференциация тувинских детей по уровню языковой компетенции на государственных языках. Только одна часть детей является активными тувинско-русскими билингвами. Вторая - увеличивающаяся - часть представлена русскоязычными монолингвами, не владеющими тувинским языком, чьи родители считают, что родной язык - «лишний предмет, мешающий учебе». И третья категория детей из сельской глубинки имеет слабую или даже нулевую языковую компетенцию на русском языке, которая не улучшается ко времени окончания школы и сдачи ЕГЭ (Сегленмей, 2016: 106).

Оценивая языковую политику в аспекте коммуникативной регламентации софункционирования тувинского и русского языков, Ч. С. Цыбенова делает вывод о том, что она направлена, «в основном, на укрепление позиций русского языка» (Цыбенова, 2017: 27). Противоречивость соотношения языковой лояльности и языкового поведения родителей выражается в том, что у них практически нет принципиального отказа от передачи родного языка. Но образование идет только на русском языке, поэтому ему отдается предпочтение, а тувинский язык дети выучат самостоятельно и стихийно в общении с родными (Сэрээдар, 2018: 13, Электр. ресурс). Н. Ч. Серээдар также приводит тревожные симптомы ухудшения языковой компетенции носителей тувинского языка, подчеркивая актуальность возврата к разумному использованию родного языка в начальных классах ... «в зависимости от реального уровня владения русским языком у поступающих в школу» (там же).

Данные по итогам массовых социолингвистических опросов, проведенных в Туве под руководством Н. Ч. Сэрээдар в 2016 г., показывают, что лишь чуть более 50\% тувинских респондентов 18-30 лет свободно владеет родным языком и около 70\% из них разговаривает на нем с детьми. Что касается возрастной группы 56 лет и старше, то в ней менее 70\% оценили свой уровень владения родным языком как свободный. Около $20 \%$ респондентов разговаривает с детьми на русском языке (Сэрээдар, 2018: 10-11, Электр. ресурс).

Приведенные данные свидетельствуют о сдвиге и в языковой лояльности, выраженной изменениями языкового поведения и увеличением доли тувинцев, не владеющих свободно родным языком, при сохранении «правильных» языковых убеждений по отношению к родному языку. По мнению исследователей, обнадеживающими являются тенденции последних десятилетий по активному переселению тувинцев из сел в города, что может оказать положительное влияние на перспективы витальности тувинского языка, так как для мигрантов характерен высокий уровень владения родным языком, являющегося языком детства и школьного образования (Монгуш, 2010: 128).

Стремление остановить языковое смещение с сохранением тувинского языка как родного без ущерба свободному владению общегосударственным русским языком стало основным лейтмотивом

\footnotetext{
${ }^{1}$ Селиверстова, Г. М. (2007) Родной язык не нужен? Как решить проблемы двуязычия [Электронный ресурс] //

Учительская газета. 8 января. URL: http://www.ug.ru/archive/22167 (дата обращения: 12.04.2019).

${ }^{2}$ Там же.

${ }^{3}$ Там же.
} 
общественного обсуждения в Туве в 2015 г., получившем освещение в он-лайн медиа дискурсе. Анализ доступных материалов выявил убедительность и обоснованность приведенной аргументации, а также активность защитников родного языка, представляющих движение «снизу» (grassroot movement).

\section{Взаимодействие субъектов языковой политики Республики Тыва}

Широкий общественный резонанс в 2015 г. вызвало открытое письмо представителей интеллигенции Тувы «О праве изучать тувинский язык», направленное руководству республики с раз-

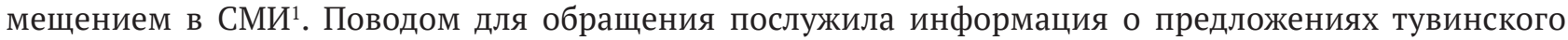
отделения Общественного народного фронта (ОНФ) по решению проблем языкового образования, включая изучение тувинского языка как второго иностранного. Можно предположить, что речь в нем шла о передаче или перенаправлении часов, отводимых в школе для обязательного изучения второго иностранного языка, на изучение тувинского как родного и государственного языка республики. Такой вариант теоретически представляется вполне разумным, и возможность его решения необходимо бы было передать на республиканский уровень.

В целом в открытом письме приводится убедительная характеристика серьезных пробелов в организации языкового образования в республике с выходом на конкретные предложения, включая необходимость разработки и принятия Государственной программы «Сохранение и развитие тувинского языка», а также формирования «двуязычия на начальном этапе образования и в средних классах, шире - многоязычия - без конфликта интересов русского, тувинского и иностранного языков и с учетом достижений мировой практики обучения языкам, не вынуждая родителей тувиноязычных детей отказываться от родного языка»².

Обращение, принятое на собрании представителей тувинской интеллигенции 2 июня 2015 г. с участием 67 школьных педагогов, ученых и преподавателей Тувинского института гуманитарных и прикладных социально-экономических исследований, Тувинского государственного университета и Управления Камбы-Ламы Тувы,является примером заинтересованной иактивнойдеятельности важного субъекта языковой политики - самих носителей языка. Ведь эффективность и бесконфликтность языковой политики обеспечивается встречным движением «сверху» и «снизу», т. е. органов власти и представителей гражданского общества.

На последовавшем за обращением круглом столе, которое состоялось в г. Кызыле 10 июня 2015 г., было продолжено обсуждение острых проблем языкового образования в республике. По информации, представленной участникам круглого стола республиканским Министерством образования и науки, в Туве четыре школы с тувинским языком обучения, остальные 143 - с русским или «смешанными языками обучения». В выступлениях участников дискуссии были приведены данные о том, что в республиканской столице изучением тувинского языка охвачено лишь $62 \%$ тувинских школьников, а в ряде школ (особенно сельских) родителей принуждают «писать отказы от изучения детьми родного языка». В разделе предложений содержатся следующие рекомендации: «разработать и принять государственную программу по сохранению тувинского языка», «добиться сбалансированного реального двуязычия...», издавать детскую литературу на тувинском языке и др. ${ }^{3}$

Активные дискуссии с участием заинтересованных субъектов языковой политики, несомненно, внесли определенный вклад в дальнейшее развитие государственной языковой политики в республике. Так, 2016 г. открылся изданием Указа Главы Республики Тыва «О Дне тувинского языка». Основным итогом работы первого республиканского форума, посвященного Дню тувинского языка в 2016 г., также стало решение о необходимости разработки государственной программы, которое было поддер-

\footnotetext{
${ }^{1}$ Открытое письмо интеллигенции Тувы о праве изучать тувинский язык (2015) [Электронный ресурс] // Тува. Азия. 2 июня. URL: https://www.tuva.asia/news/tuva/7984-otkrytoe-pismo.html (дата обращения: 20.12.2019).

${ }^{2}$ Там же.

${ }^{3}$ Монгуш, С. (2015) В государственном лицее Республики Тыва - 0\% изучающих родной язык [Электронный ресурc]// ARD. URL: http://asiarussia.ru/news/7905 (дата обращения: 20.12.2019). См. также видеозапись: https:// www.youtube.com/watch?time_continue $=7 \& v=x 7$ VyF7yqDwk\&feature $=$ emb_title

${ }^{4}$ Указ Главы Республики Тыва «О Дне тувинского языка» (2016) [Электронный ресурс] // Официальный портал Республики Тыва. 18 января. URL: http://gov.tuva.ru/press_center/news/society/22243/ (дата обращения: 20.12.2019).
} 
жано Главой республики Ш. Кара-оолом․ В 2017 г. Государственная программа «Развитие тувинского языка на 2017-2020 годы» (далее - Программа) получила официальное утверждение и находится в открытом доступе на интернет-ресурсах ${ }^{2}$.

В то же время в 2018 г. в прессе появилось сообщение о том, что Министерство образования и науки РТ издало распоряжение об обучении всех предметов с первого класса на русском языке, запрещая, таким образом, обучение на родном языке, о чем пишет С. Сегленмейㄱ. По ее мнению, данное предписание противоречит «педагогическим и психологическим принципам обучения в начальной школе», когда дети, не владеющие или плохо владеющие русским языком, вынуждены учиться по учебникам для детей с родным русским языком. Она приводит убедительное мнение К. Г. Паустовского о том, что «человек, равнодушный к своему языку, - дикарь. Он вредоносен по своей сути потому, что его безразличие к языку объясняется полнейшим безразличием к прошлому, настоящему и будущему своего народа» 4 .

Обнадеживают в какой-то степени рекомендации круглого стола в Министерстве образования и науки РТ, прошедшего 12 апреля 2019 г. в рамках Международного года языков коренных народов. Среди рекомендаций значится и разработка программы обучения родному языку в $1-4$ классах, включая математическую и естественно-научную терминологию. Не вполне понятным остается, идет ли здесь речь об обучении на языке с дополнительным вниманием к соответствующей терминологии, что было бы совершенно правильным решением. В случае, если перевод всех детей начальной школы без учета уровня владения русским языком все-таки состоялся, то можно предположить, что причиной этому являются либо невежественность чиновников в вопросах естественной и неразрывной связи языка и мышления, либо это их попытка таким образом избавиться от необходимости учебно-методического обеспечения обучения на родном языке.

Следует отметить, что в аналитической части указанной выше Программы вполне адекватное отражение получили основные проблемные аспекты функционирования тувинского языка, включая негативные последствия декларативности языковых прав, сужения сфер использования и ослабления значения тувинского языка в получении образования, снижения роли СМИ в поддержке развития тувинского языка и др. Исходя из этого, в качестве основы языковой политики республики там выделяется стратегия «сохранения и упрочения сбалансированного тувинско-русского и русскотувинского двуязычия... для гармоничного взаимодействия государственных языков республики ${ }^{5}$ Программе выделены приоритеты и сформулирована ее цель: «создание условий для сохранения, равноправного развития тувинского языка и его использования как государственного языка Республики Тыва» ${ }^{6}$.

В число ожидаемых результатов реализации Программы входят такие важные показатели, как, например, «увеличение доли выпускников... с качественным уровнем владения тувинским языком до 55\%», расширение сфер использования тувинского языка и заинтересованности населения в его изучении, а также учебно-методическое обеспечение изучения тувинского языка. В Программе логично выделены три подпрограммы с указанием финансового обеспечения и возможных рисков.

Таким образом, можно сказать, что открыт новый этап развития нормативно правовой регламентации языковой политики республики, укрепляющий и логично развивающий основы языкового законодательства, изложенные в Законе о языках Республики Тыва и в Конституции Республики Тыва.

\footnotetext{
${ }^{1}$ Об утверждении государственной программы Республики Тыва «Развитие тувинского языка на 20172020 годы» (с изменениями на 3 июня 2019 года) [Электронный ресурс] // Электронный Фонд правовой и нормативно-технической документации. URL: http://docs.cntd.ru/document/446197328 (дата обращения: 20.12.2019).

${ }^{2}$ Государственная программа «Развитие тувинского языка на 2017-2020 годы» [Электронный ресурс] // Официальный портал Министерства экономики Республики Тыва. http://mert.tuva.ru/directions/fcp/gp/31.html (дата обращения: 20.12.2019).

${ }^{3}$ Сегленмей, С. Ф. (2018) День тувинского языка. О языке обучения в начальной школе [Электронный ресурс] // ИА Туваонлайн. 1 ноября. URL: https://www.tuvaonline.ru/2018/11/01/den-tuvinskogo-yazyka-o-yazykeobucheniya-v-nachalnoy-shkole.html (дата обращения: 20.12.2019).

${ }^{4}$ Там же.

${ }^{5}$ Государственная программа «Развитие тувинского языка на 2017-2020 годы» ..., Электр. ресурс. ${ }^{6}$ Там же.
} 
Заинтересованное участие широкой научной и педагогической общественности республики в определении стратегии, цели и основных задач Программы является ее важной особенностью, позитивно характеризующей становление конструктивного взаимодействия субъектов языковой политики в Республике Тыва. Их путь к взаимопониманию и диалогу был и остается непростым. Но он позволяет выявить противоречивость между позитивным отношением к родному языку и выбором русского как языка обучения в школе в ущерб родному, с одной стороны, и ее обусловленность явной недостаточностью научного знания и образовательной информации об исключительной важности родного языка для интеллектуальной, эмоциональной и психологической успешности детей. И, кроме того, как справедливо утверждает авторитетный классик социолингвистики Д. Фишман, только возрождение или сохранение статуса родного языка позволяет остановить языковое смещение. В остальных случаях оно приводит к сохранению родного языка как второго или к потере родного языка (Fishman, 1991). Поэтому для всех субъектов языковой политики, включая семью и руководителей образовательных учреждений, важно четкое понимание стратегических целей и путей достижения или приближения к социальной справедливости, включая надежную витальность родных языков.

\section{Заключение}

Три десятилетия развития языковой политики Республики Тыва определялись как динамикой российского языкового законодательства, так и особенностями функционирования тувинского языка с учетом его параметрических и статистических характеристик в диахроническом и синхроническом аспектах. Сохранность высоких позиций тувинского языка с точки зрения его демографической мощности и правового статуса происходит на фоне негативных процессов языкового сдвига, особенно заметного у молодого поколения городских тувинцев в последние два десятилетия, а также не всегда продуманной языковой политикой в сфере образования. Достижение качественного владения родным языком для 55\% выпускников школ поставлен в качестве задачи в Государственной программе «Развитие тувинского языка на 2017-2020 годы».

Разработку и принятие данной Программы с учетом выделенных в ней приоритетов и задач, можно отнести к позитивным направлениям развития языковой политики республики. Важной особенностью языковой жизни Тувы является активное и конструктивное участие представителей тувинского гражданского общества в обсуждении проблем и угроз в сохранении и развитии тувинского языка, отражение их позиции в СМИ республики, а также готовность власти к учету их рекомендаций. Это должно будет способствовать развитию более сбалансированного и активного билингвизма, сохранению тувинского языка как родного языка титульного этноса республики, а также сохранению межэтнического согласия. Перспективным представляется продолжение исследования динамики правового и функционального развития тувинского языка в условиях контактного билингвизма и определение его места в прогностической классификации языков РФ.

\section{СПИСОК ЛИТЕРАТУРЫ}

Алпатов, В. М. (2015) Языковая политика в XXI веке // Языковая политика в контексте современных языковых процессов / отв. ред. А. Н. Биткеева. М. : Издательский центр «Азбуковник». 471 с. С. 10-19.

Алпатов, В. М. (2018) Языковая политика в современном мире // Языковое единство и языковое разнообразие в полиэтническом государстве: Международная конференция (Москва, 14-17 ноября 2018): Доклады и сообщения / отв. ред. А. Н. Биткеева, М. А. Горячева. М. : Языки народов мира. 751 с. C. 24-33.

Арутюнова,Е.М.(2018) Этноязыковые проблемы и перспективы в образовательной сфере российских республик (на примере Башкортостана) // Социологические исследования. № 4. С. 25-35. DOI: 10.7868/ S0132162518040037

Бавуу-Сюрюн, М. В. (2010) Тувинский язык на современном этапе: образовательный аспект [Электронный ресурс] // Новые исследования Тувы. № 3. URL: https://nit.tuva.asia/nit/article/view/500 (дата обращения: 06.11.19).

Биткеева, А. Н. (2018) Развитие языков Российской Федерации: динамика, проблемы, прогнозы // Вопросы филологии. № 1. С. 31-38. 
Биткеева, А. Н., Вингендер, М., Михальченко, В. Ю. (2009) Прогнозирование и языковое многообразие в Российской Федерации: социолингвистический аспект // Вестник Волгоградского государственного университета. Серия 2. Языкознание. С. 6-23. DOI: 10.15688/jvolsu2.2019.3.1

Боргоякова, Т. Г. (2002) Социолингвистические процессы в республиках Южной Сибири. Абакан: Издательство Хакасского государственного университета им. Н. Ф. Катанова. 166 с.

Боргоякова, Т. Г. (2013) Развитие билингвизма в республиках Тыва и Хакасия // Филологические науки. Вопросы теории и практики. № 7 (25). С. 36-39.

Боргоякова, Т. Г. (2018) Языки коренных народов США: терминологические и законодательные аспекты // Филологические науки. Научные доклады высшей школы. № 6. С. 36-42. DOI: 10.20339/ PhS.6-18.036

Боргоякова, Т. Г., Гусейнова, А. В. (2017) Статус и функционирование тюркских языков Южной Сибири. Абакан: Изд-во ХГУ им. Н. Ф. Катанова. 136 с.

Головко,Е.В.(2016) Современная языковая политика и проблема сохранения языкового и культурного разнообразия в Российской Федерации // Сохранение и развитие языков и культур коренных народов Сибири: материалы IV Международной научно-практической конференции (Абакан, Республика Хакасия, 19-20 мая 2016 года) / отв. ред. Т. Г. Боргоякова. Абакан: Издательство ХГУ им. Н. Ф. Катанова. 368 с. C. $9-12$.

Замятин, К., Пасанен, А., Саарикиви, Я. (2012) Как и зачем сохранять языки народов России? / отв. ред. Янне Саарикиви. Хельсинки: Vammalan Kirjapaino Оy, Vammala. 178 с.

Ламажаа, Ч. К. (2014) Засаянские тувинцы: образ жизни, ценности, идеалы [Электронный ресурс] // Новые исследования Тувы. № 3. URL: https://nit.tuva.asia/nit/article/view/138 (дата обращения: 01.11.2019).

Мартан-оол, М. Б. (2000) Проблемы и перспективы тувинского языка // Языки народов России: перспективы развития: материалы международного семинара. Элиста : АПП «Джангар». 544 с. С. 137-147.

Монгуш, М. В. (2010) Один народ: три судьбы. Тувинцы России, Монголии и Китая в сравнительном контексте. Осака : Национальный музей этнологии. 359 с.

Нерознак, В. П. (2002) Языковая ситуация в России: 1991-2001 годы // Государственные и титульные языки России. Энциклопедический словарь-справочник / под ред. В. П. Нерознака. М. : Academia. 616 с. C. 5-19.

Сегленмей, С. Ф. (2007) К проблеме билингвизма в Туве // Русский язык в Туве: Материалы республиканской научно-практической конференции (22-23 ноября 2007 года, г. Кызыл) / отв. ред. Б. К. Ондар. Кызыл : ТывГУ РИО. 138 с. С. 92-99.

Сегленмей, С. Ф. (2016) Роль родного языка как языка обучения в начальной школе // Вестник Тувинского государственного университета. № 4. С. 105-112.

Словарь социолингвистических терминов (2006) / отв. ред. В. Ю. Михальченко. М. : Институт языкознания РАН. 313 с.

Сэрээдар, Н. Ч. (2018) Тувинский язык как средство общения тувинцев: проблемы и перспективы // [Электронный ресурс] // Новые исследования Тувы. № 1. URL: https://nit.tuva.asia/nit/article/view/752 (дата обращения: 05.11.2019). DOI: 10.25178/nit.2018.1.1

Цыбенова, Ч. С. (2017) Современная языковая ситуация в Республике Тыва: социолингвистический аспект / отв. ред. Г. А. Дырхеева. Иркутск: Изд-во «Оттиск». 170 с.

Fishman, J. A. (1991) Reversing Language Shift. Theoretical and Empirical Foundations of Assistance to Threatened Languages. Clevedon \& Philadelphia. Multilingual Matters. 431 p.

Дата поступления: 20.12.2019 г.

\section{REFERENCES}

Alpatov, V. M. (2015) Iazykovaia politika v XXI veke [Language policy in the $21^{\text {st }}$ century]. In: Iazykovaia politika $v$ kontekste sovremennykh iazykovykh protsessov [Language policy in the context of modern linguistic processes] / ed. by A. N. Bitkeeva. Moscow, Azbukovnik Publishing center. 471 p. Pp. 10-19. (In Russ.). 
Alpatov, V. M. (2018) Iazykovaia politika v sovremennom mire [Language policy in the modern world]. In: Iazykovoe edinstvo i iazykovoe raznoobrazie $v$ polietnicheskom gosudarstve [Linguistic unity and linguistic diversity in a multi-ethnic state]: International conference (Moscow, November 14-17, 2018): reports / ed. by A. N. Bitkeeva and M. A. Goriacheva. Moscow, Iazyki narodov mira. 751 p. Pp. 24-33. (In Russ.).

Arutyunova, E. M. (2018) Ethno-linguistic problems and prospects in educational sphere of the Russian Republics (the case of Bashkortostan). Sotsiologicheskie issledovaniya [Sociological Studies], no. 4, pp. 25-35 (In Russ.). DOI: 10.7868/S0132162518040037

Bavuu-Surun, M. V. (2010) Tuvinskii iazyk na sovremennom etape: obrazovatel'nyi aspekt [Tuvan language on modern stage: educational aspect]. The New Research of Tuva, no. 3 [online] Available at: https://nit.tuva. asia/nit/article/view/500 (access date: 06.11.19). (In Russ.).

Bitkeeva, A. N. (2018) Razvitie iazykov Rossiiskoi Federatsii: dinamika, problemy, prognozy [The case study of the development of languages in the Russian Federation: dynamics, problems, perspectives]. Voprosy filologii, no. 1, pp. 31-38. (In Russ.).

Bitkeeva, A. N., Wingender, M. and Mikhalchenko, V. Yu. (2009) Prognozirovanie i iazykovoe mnogoobrazie v Rossiiskoi Federatsii: sotsiolingvisticheskii aspekt [Language prognosis and language diversity in the Russian Federation: sociolinguistic aspect]. Vestnik Volgogradskogo gosudarstvennogo universiteta, issue 2, Iazykoznanie, pp. 6-23. (In Russ.). DOI: 10.15688/jvolsu2.2019.3.1

Borgoiakova, T. G. (2002) Sotsiolingvisticheskie protsessy v respublikakh Iuzhnoi Sibiri [Sociolinguistic processes in the republics of southern Siberia]. Abakan, Khakass State University Press. 166 p. (In Russ.).

Borgoiakova, T. G. (2013) Razvitie bilingvizma v respublikakh Tyva i Khakasiia [Development of bilingualism in the Republics of Tuva and Khakassia]. Filologicheskie nauki. Voprosy teorii i praktiki, no. 7 (25), pp. 36-39. (In Russ.).

Borgoiakova, T. G. (2018) Iazyki korennykh narodov CShA: terminologicheskie i zakonodatel'nye aspekty [Indigenous Languages of the United States: Terminological and legislative aspects]. Filologicheskie nauki. Nauchnye doklady vysshei shkoly, no. 6, pp. 36-42. (In Russ.). DOI: 10.20339/PhS.6-18.036

Borgoiakova, T. G. and Guseinova, A. V. (2017) Status i funktsionirovanie tiurkskikh iazykov Iuzhnoi Sibiri [Status and functioning of the Turkic languages of southern Siberia]. Abakan, Khakass State University Press. 136 p. (In Russ.).

Golovko, E. V. (2016) Sovremennaia iazykovaia politika i problema sokhraneniia iazykovogo i kul'turnogo raznoobraziia v Rossiiskoi Federatsii [Modern language policy and the problem of preserving language and cultural diversity in the Russian Federation]. In: Sokhranenie i razvitie iazykov i kul'tur korennykh narodov Sibiri [Preservation and development of languages and cultures of indigenous peoples of Siberia]: Proceedings of the $4^{\text {th }}$ research and practical International conference (Abakan, Republic of Khakassia, May 19-20, 2016) / ed. by T. G. Borgoiakova. Abakan, Khakass State University Press. 368 p. Pp. 9-12. (In Russ.).

Zamiatin, K., Pasanen, A., Saarikivi, Ia. (2012) Kak i zachem sokhraniat' iazyki narodov Rossii? [How and why to preserve the languages of the peoples of Russia?]. Ed. by Ianne Saarikivi. Khel'sinki, Vammalan Kirjapaino Oy, Vammala. 178 p. (In Russ.).

Lamazhaa, Ch. K. (2014) Zasaianskie tuvintsy: obraz zhizni, tsennosti, idealy [Tuvans beyond the Sayan mountains: way of living, values and ideals]. The New Research of Tuva, no. 3 [online] Available at: https://nit. tuva.asia/nit/article/view/138 (access date: 01.11.2019). (In Russ.).

Martan-ool, M. B. (2000) Problemy i perspektivy tuvinskogo iazyka [Problems and prospects of the Tuvan language]. In: Iazyki narodov Rossii: perspektivy razvitiia: materialy mezhdunarodnogo seminara [Languages of the peoples of Russia: Prospects for development]: Proceedings of the international seminar. Elista, APP «Dzhangar». 544 p. Pp. 137-147. (In Russ.).

Mongush, M. V. (2010) Odin narod: tri sud'by. Tuvintsy Rossii, Mongolii i Kitaia v sravnitel'nom kontekste [One people, three destinies. Tuvans of Russia, Mongolia and China in a comparative context]. Osaka, Natsional'nyi muzei etnologii. 358 p. (In Russ.).

Neroznak, V. P. (2002) Iazykovaia situatsiia v Rossii: 1991-2001 gody [Language situation in Russia: 1991-2001]. In: Gosudarstvennye i titul'nye iazyki Rossii. Entsiklopedicheskii slovar'-spravochnik [State and title languages of Russia: A dictionary and reference book] / ed. by V. P. Neroznak. Moscow, Academia. 616 p. Pp. 5-19. (In Russ.). 
Seglenmey, S. F. (2007) K probleme bilingvizma v Tuve [On the problem of bilingualism in Tuva]. In: Russkii iazyk $v$ Tuve [Russian language in Tuva]: Proceedings of the scientific and practical republican conference (November 22-23, 2007, Kyzyl) / ed. by B. K. Ondar. Kyzyl, TyvGU RIO. 138 p. Pp. 92-99. (In Russ.).

Seglenmey, S. F. (2016) Rol' rodnogo iazyka kak iazyka obucheniia v nachal'noi shkole [Role of the native language as the language of instruction in primary schools]. Vestnik Tuvinskogo gosudarstvennogo universiteta, no. 4, pp. 105-112. (In Russ.).

Slovar' sotsiolingvisticheskikh terminov [Dictionary of sociolinguisticterms] (2006)/ ed. by V. Yu. Mikhal'chenko. Moscow, Institut iazykoznaniia RAN. 313 p. (In Russ.).

Sereedar, N. Ch. (2018) Tuvinskii iazyk kak sredstvo obshcheniia tuvintsev: problemy i perspektivy [Tuvan language as means of communication among Tuvans: problems and prospects]. The New Research of Tuva, no. 1 [online] Available at: https://nit.tuva.asia/nit/article/view/752 (access date: 05.11.2019). (In Russ.). DOI: 10.25178/nit.2018.1.1

Tsybenova, Ch. S. (2017) Sovremennaia iazykovaia situatsiia v Respublike Tyva: sotsiolingvisticheskii aspekt [Modern language situation in the Republic of Tuva: Sociolinguistic aspect] / ed. by G. A. Dyrkheeva. Irkutsk, Ottisk Publ. 170 p. (In Russ.).

Fishman, J. A. (1991) Reversing Language Shift. Theoretical and Empirical Foundations of Assistance to Threatened Languages. Clevedon \& Philadelphia. Multilingual Matters. $431 \mathrm{p}$.

Submission date: 20.12.2019. 